\title{
Study of Motif Role and Function in Advertising
}

\author{
Dion Darsa Sabrian \\ Master of Design \\ Universitas Komputer Indonesia \\ Bandung, Indonesia \\ dion.darsa@email.unikom.ac.id
}

\begin{abstract}
The purpose of the study was to find out the function of advertising. Motif is one of the examples decorating activities that exist to this day. Just like ornaments, it can be applied anywhere, from print ad, carving, craft, structure like building and bridge, etc. Because there is a philosophy contained, the creation of motif can't be perfunctory. So we have to think how the best way to communicate it. Application of motif in advertising can affect viewers emotionally because of the feeling of involvement there. Motif can represent Indonesia's culture diversity. This will bring out pride. It is same for the advertisers, the application of motif in the ads that they published will brand their company like " $100 \%$ Indonesian Company." Motif is kind of similar with advertising. It contains message or stories to tell. However, in reality, we rarely saw motif on advertising. The Graphic elements that often being used in ads design is just shaped, colors and the model (for the center of attention). It's dull and tedious at the same time and led to visual pollution. People need something new, something that caught the eye when saw the ads beside the model and the color itself. The application of motif can be an option to visual pollution because it has emotional effects for those who saw it, and the application of motif can also be an identity for Indonesian Advertising.
\end{abstract}

Keywords - Motif, Ornament, Advertising, Ads,

\section{INTRODUCTION}

Motif is one of the results of decorating activities that have existed since the dawn of time. Motif has many types, one of which is the traditional type. In Indonesia specifically, we can find the traditional types in batik. Chandra Tresnadi and Agus Sachari said on their research, Visuals on motif/ornaments illustrate the life sayings and values upon which the life of the community is laid [1]. Indeed, motif has an interesting philosophy to explore further, so is advertisements. Advertisement has a message to convey. This research is carried out on the basis of saturation of existing advertisements. Roger Bown in his research said Advertising is a practice which is no longer merely concerned with manipulation, but with extending the highly creative use of a wide variety of media and spawning credible cultural and stylistic trends [2]. But right now it seems that the only purpose of existing advertisements is to attract attention, not conveying messages or even bonding with targets in creative ways. Indeed, there are already a number of advertisers who are beginning to change their ways of advertising, but there are still many who have not. These ads they produce will be useless so, that they lead to visual pollution or even damage the advertiser's image itself. Effective advertising is an ad that successfully binds its target. The application of the motif can be used as an option to overcome this.

Research on the application of motif has been done before. In a study conducted by Laksmi Kusuma Wardani and Ronald Hasudungan Irianto Sitinjak discussed the variety of batik motifs and finding concepts and ideas through alternative development \& implementation of East Java batik ornamentation on modern interior design elements [3]. Another research is conducted by Agus Setiawan and Annas Marzuki Sulaiman who attempted to strengthen Jepara identity as the City of Carving through the development of a carved motif design [4]. The last is the research is conducted by Mafazah Noviana and Sujoko Hastanto. The purpose of their research is to increase people's interest, especially the people of East Kalimantan and generally Indonesian to use batik as a cultural identity of Indonesian ethnic groups [5].

The three studies mentioned show that motif can be applied to other things beside clothes. However, there has been no research that addresses the application of motives to advertisements. Therefore, the purpose of this study is to inform the role and function of the motif when applied to advertisements [6]. This research is a descriptive qualitative research with a phenomenological approach.

\section{METHOD}

This study used descriptive qualitative method with a phenomenological approach which provides a detailed description of research obtained result based on understanding process from human perspective as a subject. The research object used was the 2013 \& 2016 Djarum and BCA's Indonesia Open advertisement. This research was conducted in August 2017 - July 2018 [7]. In addition, data collection was conducted in literature study, questionnaires and interviews with competent source in motif field. In reviewing research object, it must be limited by research indicators so the research didn't get out from the specified path. The data analysis that has been used was an intraestetic data analysis, is an analytical process that sees objects seriously and considers them systematically, everything that exists and appears in the artwork [8]. 


\section{RESULTS AND DISCUSSION}

This research focused on Djarum and BCA's Indonesian Open advertisements in 2013 and 2016. In the event's advertisement, the use of motifs as a design element was obvious [9]. Harmonization between other elements was well-designed that it was easy for us to understand the message underlying the ads

\section{a. Djarum Indonesia Open 2013}
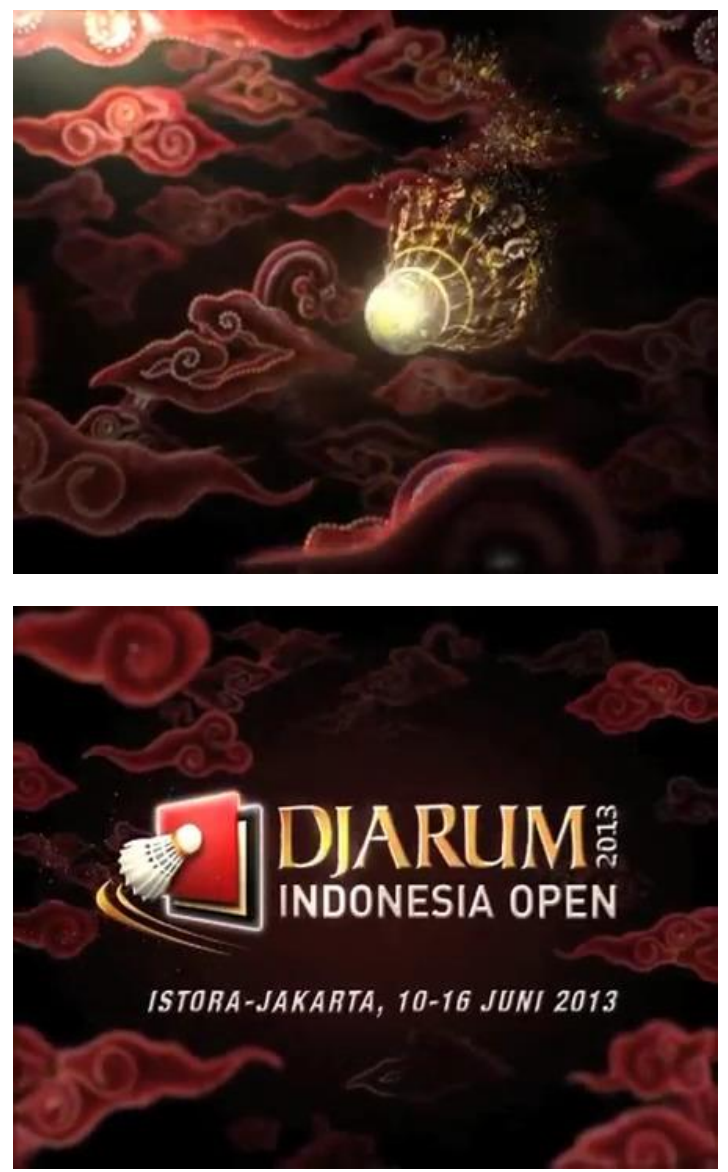

Fig. 1. Scenes of TVC Djarum Indonesia Open 2013

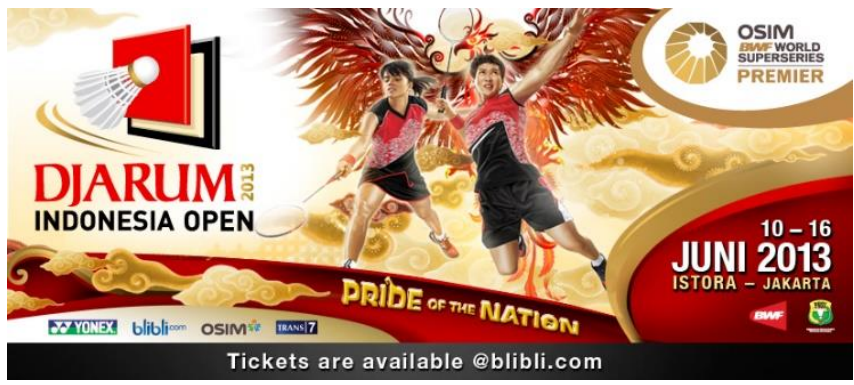

Fig. 2. Printed Advertisement of Djarum Indonesia Open 2013

As you can see in the Fig, Djarum Indonesia Open 2013 advertisement (TVC or Printed) used Megamendung motif. This motif has a deep meaning. It can be seen from the irregular curved line starting on the inside (shrinking) and extend out (enlarges) [10]. The small-then-enlarge regular curved lines indicate human life which is always changing and has its ups and downs, then developing out looking for identity and ultimately bringing itself back to nature as a human. This represents a cycle of human life. Therefore, the depiction of the megamendung motif must not be cut off for one object only [11].

Print and TV advertisements published by the organizers are well executed in delivering the message. It is simple but on point. According to the theory of branding, simplicity is convenient for it will facilitate the message to enter the target's mind. The application of Megamendung motif and the addition of garuda stylation are indeed giving a special attraction. Megamendung is a presentational symbol, which means we don't need certain rules in understanding the symbol. Even people who do not know its philosophy will automatically interpret this ad as authentic Indonesian, that it is native characteristic of Indonesian culture [12].

\section{b. BCA Indonesia Open 2016}
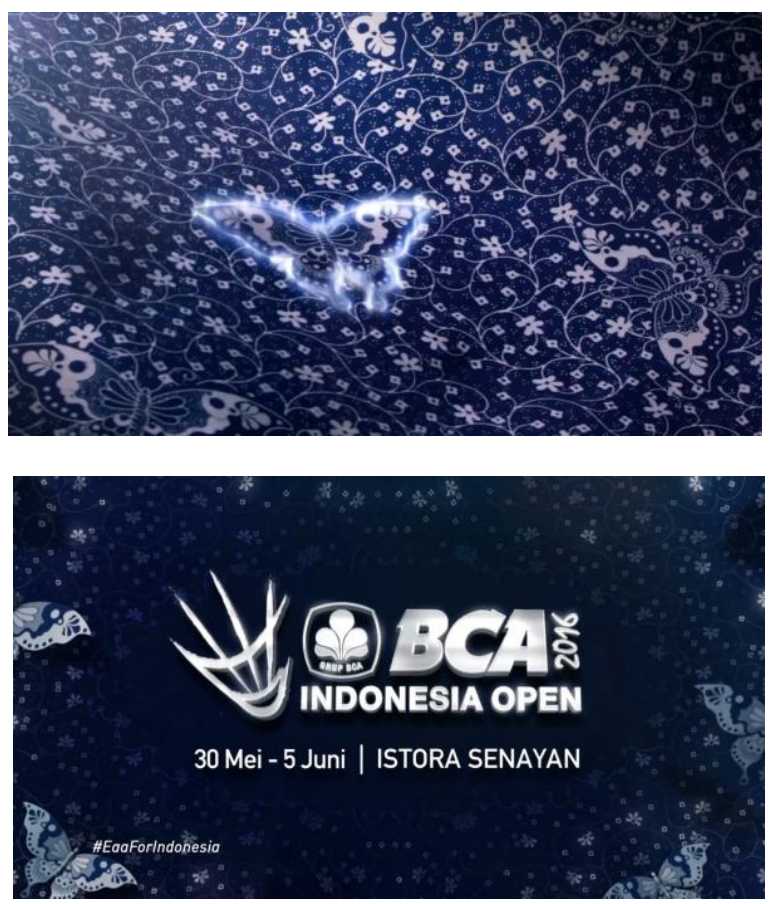

Fig. 3. Scenes of TVC BCA Indonesia Open 2016

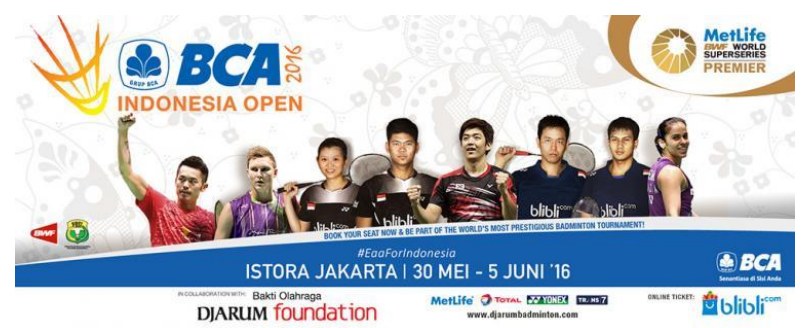

Fig. 4. Printed Advertisement of BCA Indonesia Open 2016

On BCA Indonesia open 2016 advertisement (printed or TVC), The motif used is rather universal but does not eliminate the traditional impression. Floral type motif with butterfly stylation as the main object, the supporting object use flower stylation with the tendrils arranged in such a way. This meant to tell you how beautiful Indonesia is. For print ads, the composition and color used are more harmonious 
than the Djarum Indonesia open 2013 ads [13]. Although the dominant color has changed, the combination of blue - white - gray produces a cool combination to the eye. Symbolically, as the 2013 Djarum Indonesia open advertisement, the motives that exist in this ad also do not need special rules in interpreting it [14]. Based on examples of advertisements taken as objects of research, the motifs are clearly applied and properly used [15]. Aside from giving a new nuance to the design part itself, the application of the motif reinforces the impression that Indonesia is rich and diverse in culture towards the world. Especially for print ads, both advertisements are seen using a simple layout, which emphasizes on the importance visual on the center part with supporting elements surrounding it [16]. The application of motif for both print advertisements is indeed not as the main object, the role of the motive here is only as a supporting object. But the special thing is, even though only as a supporting object the application of the motif has a considerable effect on the design itself [17]. With the right layout, the use of motifs does not damage the aesthetics of the advertisement so that it can still be enjoyed by all people. It is semiotically right, the visual language used is easily understood by anyone and also the relationship between the elements used is felt to make it easier for the wider community to absorb the visual stimuli that are given and conclude the meaning according to what they see [18].

Existing ads tend to be dull and tedious, not engaging the targets and likely using the same elements (models, text and color games and graphic forms). People need something new that involves them emotionally [19]. This is needed so that the message in the ad is conveyed in its entirety. In addition to the message, advertisers can also build the company's image on advertising. In order for these two things to run optimally, advertisers must find a good communication strategy towards the intended target [20].

When compared to American ads and Thai ads, the condition of Indonesian advertising is not far behind. There are already a number of ads that in addition to delivering messages also build images. For example, printed advertisements that are published by gojek. Gojek does not display designs at all. They play with text and layout. This is very interesting to the public, amid advertisement ads that exist such as fighting with designs that are displayed, gojek appears by only displaying text.

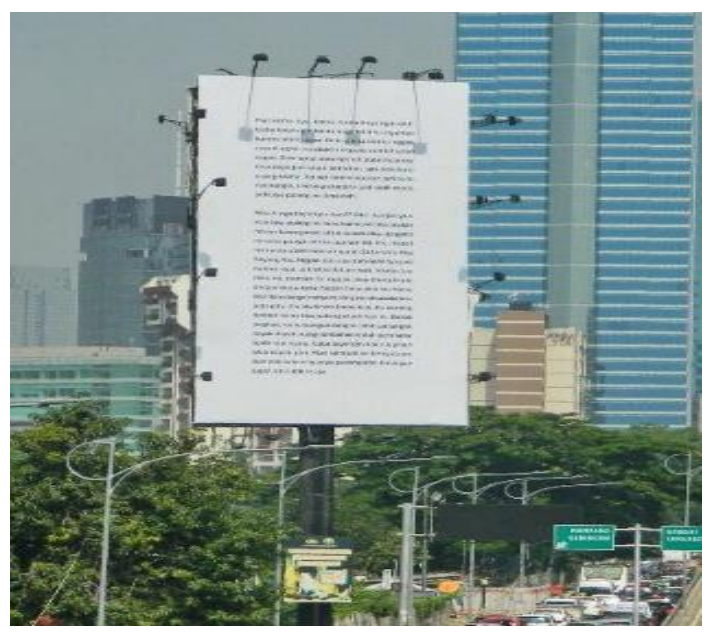

Fig. 5. Gojek Printed Advertisement
Whereas for TVC itself, it is necessary to have interesting characteristics as found in Thai ads and American ads. Thai ads have a characteristic that the storyline of advertisements can emotionally affect the target. While American ads have a characteristic story that is the development of the advertiser's tagline. This is what has not been seen in Indonesian ads. Indeed, there are those who have reformed, but there are many who "just advertise".

Application of motif can be one of the characteristics of Indonesian advertising. Keep in mind, composition plays an important role. Don't let the motive be the main point of interest. The message from the advertisement itself must remain the main thing to convey. The application of the motif is believed to reduce the saturation of advertising. There is a special attraction on that. Advertising that use motif is somehow inviting us to be proud to be Indonesian citizens who are rich in culture, have beautiful landscapes, diverse ethnic groups and many others.

This is in line with research conducted by Mafazah Noviana and Sujoko Hastanto; they argue that batik is a cultural identity of the Indonesian people.

\section{CONCLUSION}

Advertising is not only about attracting mass, it is more than that. Existing advertisements tend to be ineffective, futile and begin to lead to visual pollution. The actual ad design doesn't have to be visually appealing but interesting in ideas rather than other ads. In order for ads to be effective, targets must be tied emotionally, that is by applying motif. Motif contains deep meaning of philosophical values that also can have a psychological impact on the target.

The application of motives to advertising can indeed be used as an alternative to overcome tediosity. Because motif are also something that shows the character of Indonesia. But, it needs a process and a review, thus cannot be applied simultaneously. For starters, you might be able to follow the Indonesia Open advertisement, which is applied to national / international large-scale events / products that contain local content using traditional motif.

The use of batik motif applied to Djarum \& BCA's Indonesia Open advertisements represents cultural wealth possessed by Indonesia. This is fitting to the Indonesia Open event as it is an international event. In addition, to introduce Indonesia's culture and building Indonesia's image in the eyes of the world, these advertisements can easily absorb by target because the use of batik motif gives a pride effect of being an Indonesian citizen.

\section{ACKNOWLEDGMENT}

My gratitude to Dr. Ir. Eddy Soeryanto Soegoto as rector of UNIKOM, Prof. Drs. Yusuf Affendi Djalari, MA and Dr, Abay D. Subarna my advisor, my tutor for helping and guiding me through this research, which probably would never be complete without them. And also Mrs Morinta Rosandini M.Ds for being my interviewee 


\section{REFERENCES}

[1] Tresnadi, Chandra and Sachari, Agus. "Identification of Values of Ornaments in Indonesian Batik in Visual Content of Nikiti Game". Accessed from https://theartsjournal.org/

[2] Bown, Roger. "Advertising - A Case of Myth-Taken Identity" on The Design Journal. Aldershot: Ashgate Publishing 2003.

[3] Wardani, Laksmi Kusuma and Sitinjak, Ronald Hasudungan Irianto.. "Ragam Hias Batik Jawa Timur dan Implementasinya dalam Elemen Desain Interior". Accessed from http://repository.petra.ac.id/

[4] Setiawan, Agus and Sulaiman, Annas Marzuki.. "Pengembangan Desain Motif Ukir Untuk Aktualisasi Identitas Jepara Sebagai Kota Ukir". Accessed from: http://publikasi.dinus.ac.id/

[5] Noviana, Mafazah and Hastanto, Sujoko. "Aplikasi Motif Batik Baru Khas Kalimantan Timur pada Elemen Dekorasi Interior" Accessed from: https://publikasiilmiah.ums.ac.id/

[6] Coleman, H. Patterns of Culture. Leeds. 2008

[7] Jedlicka, Wendy. Sustainable Graphic Design. New Jersey: John Wiley \& Sons, Inc. 2008

[8] Kight, Kimberly. A Field Guide to Fabric Design. California: C\&T Publishing.Inc. 2008.

[9] Lestari, Suerna Dwi. Mengenal Jenis Batik. Jakarta: PT. Balai Pustaka. 2012.
[10] Lwin, May and Aitchison, Jim. Clueless In Advertising. Jakarta: Bhuana Ilmu Populer. 2002

[11] Moser, Mike. United We Brand. Jakarta: Erlangga. 2006

[12] Neumeier, Marty. The Brand Gap. USA: Aiga. 2006

[13] Oehlke, Horst. Mencari Semantika Obyek Desain. Dalam: Vihma, S and Vakeva, S. Semiotika Visual dan Semantika Produk. Hlm 99. Yogyakarta: Jalasutra. 2009

[14] Rosandini, Morinta. Bahan Kuliah Bagan Teknik Tekstil. Bandung: Telkom University. 2017

[15] Sachari, Agus, Dr. Estetika, Makna, Simbol dan Daya. Bandung: ITB. 2002

[16] Saidi, Acep Iwan. Dr. Narasi Simbolik Seni Rupa Kontemporer Indonesia. Yogyakarta: ISACBOOK. 2008

[17] Tjiptono, Fandy. Branding \& Brand Longevity di Indonesia. Yogyakarta: Andi. 2014.

[18] Toekio, Soegeng. Mengenal Ragam Hias Indonesia. Bandung: Angkasa. 1987

[19] Vakeva, Seppo.: Untuk Apa Kita Membutuhkan Semiotika?. Dalam: Vihma, S and Vakeva, S. Semiotika Visual dan Semantika Produk. Hlm 125. Yogyakarta: Jalasutra. 2009.

[20] Zaenab Zilullah, Wa ode. Jurnal: Pemikiran Fenomenologi menurut Edmund Husserl. 